\title{
Ecofascism and Capitalocene: Is Mankind the Real Virus?
}

\author{
Emanuel Campos Madrigal \\ Universidad Nacional de Costa Rica \\ Sebastián Miranda Brenes \\ Universidad Nacional de Costa Rica
}

In recent years, the idea that the planet is the greatest beneficiary of crises affecting human life, such as epidemics and pandemics, has gained momentum in environmental discussions. This has strengthened the discourse according to which mankind is a "plague" that must be eradicated, a concept that has been spreading in our societies for decades, driven in many cases by political and economic elites worldwide, which gives way to the possibility of establishing ecofascist forms of power, by valuing radical practices such as eugenics as a way to confront the so-called anthropocene that has led to the environmental crisis, without leaving room to point out the real cause of marking a planetary geological era: capitalism, so it would be more correct to speak of capitalocene.

Keywords: Ecofascism, pandemic, anthropocene, Capitalocene, ecological crisis

\section{INTRODUCTION}

The situation arising from the current pandemic caused by the new coronavirus has been used to promote speeches that, under the supposed defense of nature, hide other interests, whether political or economic. During the last few months, the mass media has spread the idea that "the planet" is the great beneficiary of the global shutdown, due to the population confinement in most parts of the world as an attempt to stop the proliferation of the disease caused by SARS-CoV-2.

For example, on February 28, 2020, the BBC newspaper published an article entitled Coronavirus: the unexpected benefits of the covid-19 epidemic for the environment, where it mentions that among "the unexpected consequences of the coronavirus outbreak have been cleaner air and a reduction in gas emissions that contribute to climate change" (BBC, 2020, para.1). And as a result of the closure of factories, the cancellation of thousands of flights and the reduction of public and private transport "there has been a drop of at least $25 \%$ in carbon dioxide emissions, according to calculations by Lauri Myllyvirta, of the Centre for Research on Energy and Clean Air (CREA), based in the United States"; in addition to a sharp drop in the demand for oil, until it depreciated sharply on the stock markets (Ibid., para.3).

Despite the fact that this article is not focused on the global situation surrounding Covid-19, events such as those previously mentioned have given rise to a discourse that for decades has been subtly promoted by elites in different parts of the world: placing human beings as the true virus that causes the greatest environmental damage, endangering the planet's life and the very survival of the human species. As mentioned in an article published in the Universal newspaper of Mexico dated June 9 of this year, in which 
it is mentioned that the statement "We are the TRUE virus" has become fashionable and is widely spread in social networks (Reyes, 2020), and that it has strengthened in recent months the anti-scientific and quasiessentialist propaganda. In other words, it pretends to show itself as a truth inherent to the human species.

This sort of assertion, in addition to being based on anthropological pessimism, cannot be empirically demonstrated, and at the same time opens the way for eco-fascist strategies to be consolidated. But what is it which feeds these discourses that have gained momentum as a result of the new global situation? Where do they come from and what are their objectives? In this article we will analyze, from the perspective of environmental philosophy and political ecology, these strategies promoted by the capitalist elites to continue maintaining their global hegemony and intensifying the environmental crisis in the process.

\section{HOW IS ECOFASCISM EXPRESSED?}

The ecofascist discourse has its roots in the thesis proposed by Thomas Robert Malthus, as stated in his Essay on the Principle of Population published in 1798 "that the population's capacity for growth is infinitely greater than the capacity of the earth to produce food for man" (Malthus, 2018, p. 35) and that it is necessary for the human population to be reduced proportionally to the means of subsistence.

Neo-Malthusiam approaches gained momentum in the 1970s, when in 1972 a group of scientists prepared the report The Limits to Growth, at the request of a group of businessmen, politicians and scientists known as the "Club of Rome". In this text it was argued that, if the exponential growth of population and capital is not stopped within its "natural" limits, we will face environmental collapse. Subsequently, in the 1990s, another famous environmental scientist, James Lovelock, author of the Gaia hypothesis, supported the Malthusiam thesis by openly stating that there are 6.5 billion people in excess on the planet for it to be able to "self-regulate". And more recently, the Executive Secretary of the United Nations Framework Convention on Climate Change, Christiana Figueres Ferrer (2015), has argued the need to reduce the planet's population in order to face the environmental crisis.

It should be noted that these statements are rarely expressed in a clear and direct manner, but they are part of the thinking of certain environmental movements that are sponsored by global corporations, which basically seek to shield themselves so that the climate crisis affects them as little as possible and thus not lose their socioeconomic status and political power. They have strategically used their media power to introduce this discourse as part of the collective thinking in all possible strata.

The proposals we call "ecofascist" are characterized by the fact that they pose the problem of establishing the "natural planetary limits" in terms of the human population and not according to the prevailing world-system, which, as will be explained below, is the main cause of the environmental crisis. Consequently, proposing strategies in this direction is biased and ill-intentioned, as it opens the question of who will define what the surplus population is or how the population that has to disappear will be determined, within a species that, unlike others, has no natural predators but is constantly facing social or economic crises, wars, natural disasters, famine, epidemics or pandemics, such as the one recently caused by COVID-19.

Ecofascist discourses arise from radical movements that proclaim an evolutionary supremacy based on a pseudo-scientific foundation called social Darwinism, which can be generally understood as the theory of Darwinian natural selection applied to human communities, where the natural resources that would facilitate production belong -as if it were a natural order- to the most powerful. Such was the case of the National Socialist (Nazi) party, which absorbed the German völkish movement, a powerful cultural and social current that united ethnocentrism with naturalistic mysticism, preaching the return to the land and simplicity, but avoiding racial mixing to procure the purity and superiority of the race, justifying the need for eugenics, as stated by Biehl and Standenmaier (2011, pp. 19, 21).

Eugenics is understood as the elimination of individuals with "defective" and therefore inferior genes. Such as those with malformations, mental or physical disabilities, as well as those belonging to groups considered less evolved, or those individuals who are considered naturally condemned, as in the case of poor, migrant and third world populations. All in order to improve the racial, physical or mental qualities of future generations of the human species (Orduna, 2008). 
Even when Nazism was defeated after World War II, these discourses did not disappear, but have prevailed in an important sector of the world's ultra-right elites who, under the international regulatory framework, work in accordance with the stipulations of organizations such as the World Bank, the International Monetary Fund and large corporations, allowing processes of environmental and economic degradation in the most impoverished countries, as stated by Alberto Acosta:

This kind of external economic aggression has created peripheral economies where the surplus is appropriated by foreign capital and wasted in unproductive consumption by the elites and middle sectors, as a result of the same dependent insertion of the impoverished world into the world economy. (Acosta, 2016, p. 8)

These strategies avoid indicating as responsible for the depredation and devastation of nature the capitalist socio-economic system, which through its economistic, urbanistic and industrialized model, violates the planetary boundaries, human rights and the carrying capacity of any natural geographic space, understanding carrying capacity as "the number of individuals in a population that a habitat can sustain" (Sánchez, 2011, p. 57), through multinational corporations and with the complicity of the same states. However, if it is a matter of assigning blame, it is not so simple either. In this regard, Jorge Orduna comments that "Institutions, like companies or States, are not good or bad because of the people who are part of them, but because of the conditioning framework in which they are involved" (Orduna, 2008, p. 7).

In poor or third world countries that participate in capitalism as suppliers of raw materials, basing their economy on the extractivism ${ }^{1}$ of natural resources, generally granting concessions to large corporations that have expelled entire native peoples from their territories, they have devastated the environment in different ways. One of these has been open-pit mining, promoting extensive deforestation, overexploiting the oceans, privatizing water resources through the commercialization of bottled water, among other destructive practices. Meanwhile, they use the mass media to confuse the population of these countries with discourses dressed up as sustainable practices, thus hindering the identification of those directly responsible and, on the contrary, the affected populations themselves come to their defense, criminalizing those minority groups that protest against them.

These eco-fascist discourses, i.e., those in the manner of business practices that promote sustainable strategies but at the same time wield ideologies of supremacy that make them appear as legitimate owners of the world's natural resources, have gained strength in the current context of the new coronavirus pandemic. All this serving as a presumed proof that corroborates such ideologies, and that leads to a tension between centralizing and hyper-controlling flows within a hierarchical political project. As Carlos Taibo (2016) explains, a project that deploys measures of immigration prohibition, strict birth control or closure of vital perspectives for the elderly.

To justify ecofascist discourses, these groups have appropriated a concept that emerged in 2002 attributed to Paul Crutzen, Nobel Prize winner in Chemistry, which makes mankind responsible for marking a planetary geological era, called "Anthropocene" and leading to the current environmental crisis. However, making an analysis from the perspective of environmental politics and ethics, it is more than clear that the ecofascist discourses are promoted by the great figures of the capitalist system that has been imposed globally and that has led to a geological era marked by the massive extinction of species and the climatic transformation of the planet, so it would be more accurate to call it Capitalocene.

\section{FROM THE ANTHROPOCENE TO CAPITALOCENE}

Environmentalism is a social movement that emerged in the 1960s, and since its inception has focused on transforming human societies culturally and economically. But, as Biehl and Standenmaier (2011) state, like all social movements that emerge from different contexts, they tend to branch out and are exposed to be influenced by causes at the service of a criminal savagery that seeks to capitalize on the widespread concern about the environmental social issue and promote their regressive agendas. 
Such is the case of green capitalism, which has been established over the last forty years to maintain this predatory capitalist system in force, using the concept of sustainable development. A concept that considers the environment as natural capital to maintain the dynamics of the markets and that, if in the past the eugenics of the poor justified it based on the needs of capital, now uses it to support a supposed commitment to the planet and its preservation. This is because the leaders of this movement do not accept as a possibility the decline of their economies, the main cause of the environmental crisis, reinforcing their roles as managers and dominators of resources.

In order to better understand how different environmental organizations are aligned in favor of global elites, Orduna (2008) refers to the example of the WWF (World Wildlife Fund), which has been accused on several occasions of practices of dubious environmental ethics, for which they have had to adopt different strategies in order to hide or conceal information. An example of these was established in 1977 by its director at that time, Charles de Haes, a lawyer who, it should be noted, lacked "any ecological or conservationist qualifications" for the position (Ibid., p. 54), creating an internal regulation that prevented the organization's workers from discussing the organization with outsiders.

But it should be noted that not all capitalist discourse allegedly committed to the environment is ecofascist in nature. One of the characteristics of the latter is to point to external culprits in the decisionmaking process, insisting that the environmental problem is caused by disproportionate population growth, promoting the idea that mankind is the "virus". Therefore, it is necessary to address this situation efficiently by opting for a quick and forceful decrease in the number of human beings and avoid the advance of the alleged Anthropocene (Taibo, 2016).

In a 2014 publication, Fischer et al. $(2014$, p. 9) attempted to provide a synthetic definition of what to understand by Anthropocene, indicating that this concept designates the time when mankind became a planetary force compared to the geological and climatic forces that have defined the phases of Earth's history, and that it has been marked by at least three ages. The first one was the transition from hunters and gatherers to farmers that began approximately 12,000 years ago; the second was the industrial transformation, i.e., the time when the industrial era was developed on a global scale in the 18th century. This stage was proposed by Crutzen and Stoermer, according to the authors, in 2000; and finally, the socalled Great Acceleration, which describes a process of rapid global growth after World War II.

It is obvious that the categorization proposed by Fischer and his colleagues follows the same line of Paul Crutzen's research work. In more detail, Cruzten (2002) stated that the Anthropocene is an age that started at the end of the 18th century, when research about air trapped in the glacial pole indicated that there was an increase in the concentration of carbon dioxide and methane; the same time that James Watson invented the steam engine. This influence on the environment was also recognized in 1873 by the Italian geologist Antonio Stoppani.

Other data Crutzen uses to demonstrate his temporal delimitation are: 1) The increase in world population over the last three centuries, now exceeding 7 billion people, which has led to a significant increase in the production of carbon dioxide and methane, and which is the main justification for driving ecofascist strategies; 2) Between 30\% and 50\% of the earth's surface has been anthropically exploited; 3) Industrial fishing removes about $25 \%$ of fish emergence zones and $35 \%$ of temperate regions; 4) Energy consumption has increased more than tenfold in the 20th century compared to the pre-industrial era and, with it, the emission of carbon dioxide as most energy production depends on the combustion of nonrenewable fossil fuels; 5) More nitrogen is used in agricultural fertilizers, also derived from petroleum to increase field production; 6) Huge quantities of non-biodegradable waste and toxic substances from the chemical industry are released into the environment.

In a separate study, Crutzen (2006) shows that the destruction of the ozone layer is caused by persistent and photoreactive materials derived from chlorofluorocarbons that decompose the ozone accumulated in the stratosphere, located more than $30 \mathrm{~km}$ from the earth's surface, and that climate change is mainly produced in the troposphere due to the accumulation of greenhouse gases from the burning of fossil fuels and the food industry, among others. However, Crutzen (2002, p. 23) through his studies concludes that these effects have been caused mainly by only $25 \%$ of the world's population. In a similar way Soriano (2018) states that there is enough empirical evidence to affirm that the ecological crisis has been produced 
specifically by the fourth part of mankind, so that the whole species cannot be blamed in a generalized sense, but has been caused by the globally established capitalism supported by different regulatory institutions.

This demonstrates that the ecofascist discourses based on the Malthusiam principle do not have a solid foundation and it is evident that they are multiplied in order to favor a few reduced groups. In addition, the need to use the concept of Capitalocene, instead of an Anthropocene, as proposed by environmental historian Jason Moore, who confessed that the first time he heard the use of this concept was from human ecology professor Andreas Malm, who together with his colleague, Alf Hornborg, have been pioneers in the discussion of this term (Moore, 2016).

These authors explain that the Anthropocene reflects the union of the Earth System analysis of the natural sciences and the post-Cartesianism ${ }^{2}$ of the social sciences represented by Bruno Latour, in which the distinction between Nature and Society is obsolete. As a result, mankind is recognized as a geological force just as other natural forces. In fact, economies and technologies conform socio-natural hybrids that demonstrate the link between human beings and nature, and that the life production and reproduction of the former is inseparable from the latter. In this sense, Hornborg and Malm $(2014$, p. 99) do not challenge the existence of an ontological dualism ${ }^{3}$, but the need to maintain an analytical dualism, as Hornborg (2017) mentions on another of his studies where he states that, "as long as nature and society are more intertwined with empirical reality, they denote aspects that must be kept analytically separate, expressing themselves as symbolic and pre-symbolic phenomena".

It should be noted that the distinction Hornborg describes is not absolute, but arises due to the analytical differences between the fields of study and their objects. In this regard, Alf Hornborg and Andreas Malm hold a position similar to Marx's, described by Kohei Saito (2017), who states that Moore confuses form dualism with matter dualism. According to Saito (2017), Marx assumed a dualistic approach at a strictly methodological level, in order to reveal the metabolic character of productive and reproductive relations in the capitalist system. However, the metabolism concept encloses the ontological unity between human beings and matter, nevertheless, he assumed a dualistic approach to more easily explain how in capitalist societies a dissociation between subject (worker) and world (resources) was generated. Similarly, it is necessary to maintain a certain analytical dualism when examining semiotic aspects in relation to biophysical ones, especially because of the hyper-relativistic consequences that have arisen due to their analytical unification, on the one hand, and the loss of perspective when analyzing issues such as human agency over the environment, on the other. By supporting this confusion, those responsible for the environmental crisis seem to be the artifacts and the way in which human social relations are structured, and it is for this reason that technocratic discourses would emerge -as a support to the interests we have exposed- to solve the ecological crisis.

In fact, a repeated criticism of the Anthropocene stems from its technocratic bias when it proposes its analysis and the solutions that emerge from it. Crist (2016), Altvater (2016) and Hartley (2016) state that authors such as Ray Kurzweil and Paul Crutzen do not consider in their works the need for social change and instead propose geoengineering, where technology is the vehicle through which global warming, for example, can be stopped. In other words, technology is worshipped and comes to function as a kind of religious totem that magically blurs all delicate situations, as Taibo (2016) rightly states, and which in turn can be at the service of ecofascisms.

In this sense, Altvater points out that the defenders of the Anthropocene concept make the same mistake Albert Einstein made in his time: thinking that mankind can solve its problems by means of the same methods that caused them. This happens, according to Crist (2016), because they conceive the Earth as a center of operations, so he finds an anthropocentric bias in these authors, since they use a language that disregards the experiences of the rest of the species and that, on the contrary, preponderates a "Promethean" account of a species that is distinguished from all others. From this perspective, the proposal of these practices and solutions is focused on maintaining control over nature, prevailing a vision of superiority that comes to light every time major global crises occur; in this way it can be understood how these discourses and ideologies proliferate almost naturally in situations that affect almost the entire world, such as the recent pandemic. 
Indeed, when a pandemic breaks out and its impacts transcend the borders of a large number of countries, it is not unusual to notice how it is placed within the framework of the ecological crisis, and therefore, it is easier to focus its causes on the human being as the main problem, but not as a consumer being, but as a species that is so numerous that it can easily spread diseases when there are no international structures prepared to deal with them. This, shall we say, normalized thinking prevails in the globalized Western culture and prevents the species from integrating into the community of life and dismantling the capitalist economic system, which is the main cause of this environmental crisis.

Moore (2016) states that the Anthropocene concept was crystallized in the following formula:

$$
\text { Human action }+ \text { Nature }=\text { Planetary crisis }
$$

This green arithmetic, as Moore calls it, although it has positioned nature, which until then had been invisible, in the perspective of the social sciences, has also placed the responsibility on mankind. This is, as Hornborg (2016) says, one of the problems associated with naming the event "The Human Age" Another criticism has related to the adjudication of the subject responsible for the ecological crisis, as Moore (2015 and 2016) and Bonneuil and Fressoz (2016) state in other works, when they point out that the Anthropocene is generated by an abstract and undifferentiated subject as responsible for environmental degradation: mankind. When in reality there are countries or more specifically groups that are more responsible than others for the environment destruction, or alternatively, there is a relational logic between human beings-nature that is mediated by capitalist relations. Hornborg (2016) notes the same criticism in a different direction. For him, Anthropocene theorists make a serious mistake when they establish these concepts based on a supposed immanentist logic, that is, that the planetary ecological crisis is a consequence of the way our species is constituted.

This is why the Capitalocene represents a better analytical category to understand the causes of the planetary ecological crisis. Although capitalism is a human production, it is not unavoidable or natural to its condition, but a historical contingency that has been driven and imposed by small groups of power at a global level, establishing a hegemonic system that has taken nature, animals and the majority of the human species into its service. In other words, industrialization and modernity supported by capitalism are unequal processes at the global level, therefore, not applicable to all, and because of the link between these and the climate crisis and environmental deterioration, it would be more appropriate to change the definition of Fischer et al. (2014) previously referred to, to capitalism (instead of mankind), which has become a planetary force comparable to the geological and climatic forces that have defined the phases of the Earth's history. Or on the other hand, paraphrasing Carlos Taibo (2016), it can be concluded that capitalism has become a genuine geological force that has come to alter the climate and has allowed the destruction and squandering of many of the elements that make up the natural environment.

However, this concept may not be well received by the environmental sectors that are involved in elitesponsored programs, nor by the governments of most countries in the world that have capitalist economic productivity as their engine of development. All this can lead to or strengthen an eco-fascist logic, since these groups do not yield to the infinite growth logic, as stated in goal 8 of the 17 Sustainable Development Goals, established by the UNDP (2020), which aims to stimulate sustainable economic growth, currently called "green growth", by increasing productivity levels and technological innovation, encouraging policies that stimulate entrepreneurship, even knowing in advance that the planetary limits have been exceeded because of the same economic system. Therefore, other goals such as End Poverty (Goal 1), Zero Hunger (Goal 2), Health and Well-being (Goal 3), among others, would be practically impossible to achieve, since the economic model itself prevents it, and during the last 30 years there has not been enough political will to achieve them.

On the contrary, even aware about the severe consequences of the climate crisis caused by the Capitalocene, which would suggest the need to seek the degrowth of powerful economies to ensure a fair and equal distribution and achieve the reduction of inequalities (Goal 10), it is necessary to adopt strong policies that empower low-income people and promote their economic inclusion, which is also practically 
impossible under the corporativist logic of the free market, hyper-production and hyper-consumption (UNDP, 2020).

Therefore, these global measures are designed to protect these groups that have a tendency towards ecofascism, leaving the majority of their fellow human beings and other species in danger of collapse. An example of this is the current case of the pandemic, where the populations most affected by the virus are the most impoverished and vulnerable, and those who do not have access to good food, health systems or basic medicines. Ecofascist groups take advantage of the health emergency caused by COVID-19 to promote the need for a reduction in the size of the human population and seek a "natural balance" between resources and population, to restart with a cycle (Orduna, 2016, p 13), which at the same time is inconsistent with a system that needs both producers and consumers to continue to exist.

\section{CONCLUSIONS}

Environmental organizations must remain alert to the development of policies by certain environmental groups financed or supported by the elites, which can promote eco-fascist principles that disguise a destructive economic system such as capitalism, making it look like a green system compatible with life. Some conclusions reached by different studies that have denied the environmental crisis or climate change must be confirmed with other analyses, and it is necessary to encourage politically and internationally to review the reference frameworks from which they start, which in many situations do not take into account the particular cases in relation to global systems, so that a stronger international collaboration is necessary. As Biehl and Standenmaier (2011) state, environmental organizations must preserve integrity and remain in the struggles for social justice, for the demands of oppressed peoples and overcome the anthropocentric construct to include in their efforts the well-being of other species and of nature, adopting a vision that moves completely away from any neo-Malthusiam proposal.

In global crisis situations, such as the most recent one caused by COVID-19, one of the public and political discourses that has been strengthened is that of the human being as a virus affecting the planet that shelters an infinite number of beings. As we have already seen, this idea is gradually gaining ground in the social perception and is extremely harmful, as it may open the way for more radical movements that promote explicitly ecofascist policies, or for political figures to come to power who promote governments that praise the end of immigration, population reduction and greater support for the privatization of natural resources, supported by groups of scientists and environmentalists who endorse such ideas, even internalizing racist, the aporophobia or ${ }^{5}$ xenophobic discourses under the mask of the fight against the environmental crisis.

Finally, it is essential to understand that planetary limits have already been exceeded because of a particular economic model: capitalism, which, although it is a system created by humans, is not inherent to the species. So it has been this, and not Homo sapiens, the main cause of the mass extinction of species in recent decades, of climate change and of marking a geological era called Capitalocene, placing the human being him/herself before the possibility of extinction. Capitalism, as a human invention, should not be an impediment for humanity to readapt to the new conditions of life, and this also requires that both national and international policies aim towards this end, aware that it is possible to adopt alternative economic systems that can even be considered as subsystems of the biosphere, as Taibo (2016) quotes Herman Daly, an American ecological economist, and thus achieve a better quality of life for all the inhabitants of the planet.

\section{ACKNOWLEDGEMENT}

Translated \& edited by American Publishing Services (https://americanpublishingservices.com/). 


\section{ENDNOTES}

1. By extractivism we will understand in a general sense "those activities that remove large volumes of unprocessed (or limited) natural resources, especially for export according to the demand of the central countries" (Acosta, 2016, p. 2).

2. Understood as the dualistic conceptions adopted by different philosophers in opposition to empiricism. One of the Cartesian currents was the materialistic-mechanistic conception of nature, such as that of Julien de La Mettrie, beyond the metaphysical duality of mind-body.

3. Concerning this point, Hornborg (2017) states that Marxism is a useful approach to overcome Cartesian dualisms.

4. In this regard, although the author does not state it directly, it is a reference to the work published in 2015 by Richard Monastersky: The Human Age. He was a member of the research group led by Jan Zalasiewicz: Anthropocene Working Group.

5. A concept introduced by Adela Cortina. It is understood as the repulsion or rejection feeling towards poor or socially excluded people.

\section{REFERENCES}

Acosta, A. (2016). Las dependencias del extractivismo. Aporte para un debate incompleto. Revista Aktuel Marx, 20. Nuestra América y la Naturaleza Santiago de Chile 2016.

Altvater, E. (2016). The Capitalocene, or, Geoengineering against Capitalism's Planetary Boundaries. In J. Moore (Ed.), Anthropocene or Capitalocene? Nature, History, and the Crisis of Capitalism (pp. 138-152). Oakland: Kairos PM.

Angus, I. (2016). Facing the Anthropocene. Fossil Capitalism and the Crisis of the Earth System. New York: Monthly Review Press.

BBC. (2020). Coronavirus: Los inesperados beneficios de la epidemia de covid-19 para el medioambiente. Retrieved from https://www.bbc.com/mundo/noticias-51664432

Bonneuil, C., \& Fressoz, J. (2016). The Schock of the Anthropocene. The Earth, History and Us. New York: Verso.

Ceballos y otros. (2015). Accelerated modern human-induced species losses: Entering the sixth mass extinction. Retrieved from https://advances.sciencemag.org/content/1/5/e1400253.full

Crist, E. (2016). On the Poverty of Our Nomenclature. In J. Moore (Ed.), Anthropocene or Capitalocene? Nature, History, and the Crisis of Capitalism (pp. 14-33). Oakland: Kairos PM.

Crutzen, P. (2002). Geology of mankind. Nature, 415, 23.

Crutzen, P. (2006). The Anthropocene: The Current Human-Dominated Geological Era. Pontifical Academy of Sciences, 18, 199-211.

Ferrer, C. (2015). Christiana Figueres; Debemos hacer todo lo posible para despoblar el planeta. Retrieved from https://eurasiahoy.com/08072015-christiana-figueres-debemos-hacer-todo-loposible-para-despoblar-el-planeta/

Fischer, M., Krausmann, F., \& Pallua, I. (2014). A sociometabolic reading of the Anthropocene: Modes of subsistence, population size and human impact on Earth. The Anthropocene Review, 1(1), 8 33.

Foster, J. (2000). La ecología de Marx. Materialismo y naturaleza. Barcelona: El Viejo Topo.

Hartley, D. (2016). Anthropocene, Capitalocene, and the Problem of Culture. In J. Moore (Ed.), Anthropocene or Capitalocene? Nature, History, and the Crisis of Capitalism (pp. 155-165) Oakland: Kairos PM.

Hornborg, A. (2017). Artifacts have consequences, not agency: Toward a critical theory of global environmental history. European Journal of Social Theory, 20(1), 95-110.

Hornborg, A., \& Malm, A. (2014). The geology of mankind? A critique of the Anthropocene narrative. The Anthropocene Review, 1(1), 62-69.

Lewis, S., \& Maslin, M. (2015). Defining the Anthropocene. doi:10.1038/nature14258 
Lewis, S., \& Maslin, M. (2015a). A transparent framework for defining the Anthropocene Epoch. The Anthropocene Review, 2(2), 128-146.

Malm, A. (2016). Fossil Capital. The Rise of Steam Power and the Roots of Global Warming. London: Verso.

Malthus, T. (2018). Primer ensayo sobre la población. Titivillus, ePub r1.0. p. 35. Retrieved from https://lectulandia.eu/book/primer-ensayo-sobre-la-poblacion

Monastersky, R. (2015). The Human Age. Nature, 519, 144-147.

Moore, J. (2015). Capitalism in the Web of Life. New York: Verso.

Moore, J. (2016). Anthropocene or Capitalocene? Nature, History, and the Crisis of Capitalism. Oakland: Kairos PM.

Orduna, J. (2008). Ecofascismo. Las internacionales ecologistas y las soberanías nacionales. Argentina: Planeta.

PNUD. (2020). Objetivos de desarrollo sostenible. Retrieved from https://www.undp.org/content/undp/es/home/sustainable-development-goals.html

Reyes, P. (2020). ¿Somos los humanos un virus? Retrieved from https://www.eluniversal.com.mx/opinion/pedro-reyes-flores/somos-los-humanos-un-virus

Saito, K. (2017). Marx en el Antropoceno: Valor, fractura metabólica y el dualismo no-cartesiano. Retrieved from http://marxismoyrevolucion.org/?p=752

Sánchez, A. (2011). Conceptos básicos de gestión ambiental y desarrollos sustentable (p.57). México: Secretaría de Medio Ambiente y Recursos Naturales.

Soriano, C. (2018). The Anthropocene and the production and reproduction of capital. The Anthropocene Review, 5(2), 202-213.

Zalasiewicz, J., \& Otros. (2015). Colonization of the Americas, 'Little Ice Age' climate, and bombproduced carbon: Their role in defining the Anthropocene. The Anthropocene Review, 2(2), $117-127$. 